\title{
The success of rock translocation for populations of the chasmophytic Aeollanthus saxatilis (Lamiaceae)
}

\author{
Sylvain Boisson $*^{\prime}{ }^{1}$, Audrey Labonté ${ }^{1}$, Grégory Mahy, Arnaud Monty \\ Biodiversity and Landscape, TERRA, Gembloux Agro-Bio Tech, University of Liège - Passage des Déportés, 2 - Gembloux, BE-5030, Belgium
}

\section{A R T ICLE INFO}

\section{Keywords:}

Chasmophytic plant population

Demographic structure

Flower visitor

Katangan copperbelt

Metallophyte

Mutualistic interaction

\begin{abstract}
A B S T R A C T
To ensure the rescue, temporary conservation and further restoration of plant populations and communities threatened by exploitation, translocation appears to be an appropriate method in the context of mining. Little is known, however, on its effect on mutualistic interactions, such as pollination, and on the resulting plant population dynamics. Whole-rock translocations were performed as a conservation strategy for the endemic metallophyte flora of Katanga, Democratic Republic of the Congo. The aim of this study was to quantify the flower visitation, sexual reproduction and ramet demographic structure in such a translocated population, and to compare the data with those from natural populations of Aeollanthus saxatilis, one of the threatened species of the chasmophytic community. The study also documented the plant's flower visitor guild. The ramet density, demographic structure, pollination success and seed abortion rate were assessed in 10 quadrats per population, in the translocated population and in two subsisting natural populations. The flower visitation rate was quantified during three observation periods ( $20 \mathrm{~min}$ each) in six quadrats per population.

Small differences were observed in the visitor guild between the translocated and natural populations, but the flower visitation rate was equivalent. No clear difference in the reproductive performance or ramet demographic structure of the populations was found. The flower visitor guild was mainly composed of generalist pollinators, which probably helped in establishing a functional visitor guild at the receptor site.

Rock translocation therefore appears to be an encouraging approach, allowing the conservation of functional mutualistic interactions and the maintenance of a population structure comparable to that of natural chasmophytic plant populations.
\end{abstract}

\section{Introduction}

Restoration success is usually assessed through community or ecosystem approaches (Harzé et al., 2018; Montalvo et al., 1997). Only a few studies have explored population attributes, such as demography and vegetative or reproductive performances, following restoration, and among these, even fewer have dealt with rare or threatened species. However, population ecology can be useful for evaluating restoration success when particular species are targeted (Harzé et al., 2018; Montalvo et al., 1997), and some of the nine attributes of successfully restored ecosystems listed by the Society to Ecological Restoration (2004) indirectly include population traits. At the population level, a successfully restored or translocated ecosystem should provide favourable abiotic conditions for population reproduction, growth, migration and adaptive evolution, in order to ensure long-term viabil- ity (Montalvo et al., 1997). Evaluations of demographic and reproductive attributes of restored populations are therefore to be encouraged.

Mutualistic interactions, such as pollination and seed dispersal, are essential for ensuring the sexual reproduction of most angiosperms, and shape the long-term demography of species (Byers \& Chang, 2017; Vanbergen et al., 2013). Plant-pollinator interactions are an important process that need to be re-established in restored ecosystems (Forup, Henson, Craze, \& Memmott, 2007). To evaluate success of restoration, a common method is to study plant-pollinator interactions at the community scale (Kaiser-Bunbury et al., 2017; Stpiczyńska \& Zych, 2017), but focusing on endemic or endangered species is also crucial in order to adapt conservation and restoration actions (Giovanetti, Cervera, \& Andrade, 2007; Monty, Saad, \& Mahy, 2006; Tepedino, Sipes, \& Griswold, 1999). Obligate pollination mutualism between plants and pollinators are rare, and plant population size, spatial arrangement

\footnotetext{
* Corresponding author.

Email address: sylvain.boisson@ulg.ac.be (S. Boisson)

1 Equally contributing authors.
} 
and environmental conditions are likely to modify the guild and the relative importance of flower visitors (Kato \& Kawakita, 2017; Kearns, Inouye, \& Waser, 1998). When flower pollination only relies on a few specialist species, habitat modifications are even more likely to alter visitation, seed set and demography (Cropper \& Calder, 1990; Monty et al., 2006). For instance, variations in insect visitation may significantly affect seed set, and are an important component of individual plant fitness and population demographic structure (Kirchner et al., 2005; Tarasjev, 2005).

In southeastern Democratic Republic of the Congo (DRC), the Katangan Copperbelt ranks amongst the most important copper-cobalt (Cu-Co) resources in the world (Cailteux, Kampunzu, Lerouge, Kaputo, \& Milesi, 2005; Mudd \& Jowitt, 2018). Katangan Cu-Co outcrops appear as scattered hills (Brooks, Baker, \& Malaisse, 1992; Duvigneaud \& Denaeyer-De Smet, 1963). Due to their eco-geographical isolation and strong selective pressures linked to high metal toxicity (Baker, Ernst, Van der Ent, Malaisse, \& Ginocchio, 2010), these metalliferous sites support unique vegetation, with metallophyte communities including endemic and threatened species (Boisson et al., 2017; Faucon et al., 2010, 2016).

Three types of plant communities that depend on the Cu-Co gradients, the $\mathrm{pH}$ and the depth of soil have been identified in these ecosystems (Ilunga wa Ilunga, Séleck, Colinet, Meerts, \& Mahy, 2013; Malaisse, Brooks, \& Baker, 1994; Muyumba, Liénard, Mahy, \& Ngongo, 2015; Saad et al., 2012; Séleck et al., 2013). Two grassland communities have been largely studied in terms of their structure, composition and plant-soil relationships: these are the steppic savanna on the lowest and intermediate $\mathrm{Cu}-\mathrm{Co}$ concentrations, supporting dense vegetation, and the steppe on the highest Cu-Co concentrations, supporting species that are tolerant to metals and drought (e.g. Boisson et al., 2020; Delhaye et al., 2016; Ilunga wa Ilunga et al., 2013; Lange et al., 2014; Le Stradic et al., 2016; Saad et al., 2012; Séleck et al., 2013). The third community develops on very rocky and highly mineral habitats that are made of cellular siliceous rocks (CSRs). These rocks present cavities where substrate aggregates, and are found at the top of the outcrops (Malaisse, Schaijes, \& D'Outreligne, 2016). The CSRs were originally silicified algal dolomites, but they have been altered to a mixture of silica and dolomite (Fay \& Barton, 2012). The distinctive chasmophytic communities that develop on CSRs include six of the 56 endemic taxa of the Katangan Copperbelt: Aeollanthus saxatilis, A. subacaulis var. linearis, Batopedina pulvinellata subsp. pulvinellata, Faroa malaissei, Euphorbia cupricola and E. fanshawei (Copperflora.org: Boisson, Lebrun, Séleck, \& Mahy, 2012; Malaisse et al., 2016). One of them (A. saxatilis) is on the IUCN Red List.

Although the most effective conservation measure would be the in situ preservation of large Katangan Cu-Co outcrops (International Council on Mining \& Minerals, 2006; Saad et al., 2012; United Nations, 1992), the increasing demand for $\mathrm{Cu}$ and Co make this unlikely to happen (Boisson, Monty, Lebrun, Séleck, \& Mahy, 2016; Brooks et al., 1992). Mining societies have established ecological restoration programmes, such strategies involve the transfer of intact mats of steppe and steppic savanna vegetation, including the plants, their entire root systems and their associated soils, from sites destined to be exploited to receptor sites (Le Stradic et al., 2016). The chasmophytic community is also part of this programme through the translocation of entire CSRs to receptor sites. This presents an opportunity to address restoration success via a population approach.

To ensure the rescue and temporary conservation of plant species for further restoration, the receptor site should allow the establishment and long-term persistence of the translocated populations through appropriate ecosystem functioning, including biotic interactions and stable abiotic conditions over time (Bullock, 1998). For the translocation of an entire CSR to another site in the same region to be successful the abiotic and biotic conditions should not vary because these alter the population structure and functioning. Such conditions include changes of the CSR's direct environment and the location of the site in the landscape, which can affect the individual fitness of the population and/or cause changes in the flower visitor guild.

This study aimed to evaluate the success of CSR translocation to a receptor site, focusing on a strictly endemic, 'Near-Threatened' plant species of the chasmophytic community (Faucon et al., 2010) - A. saxatilis P.A. Duvign \& Denaeyer-De Smet, 1963 (Lamiaceae). This species was selected as the study model because we were in determining whether pollinators would be lacking at the receptor site, thus leading to a decrease in sexual reproduction and altering the demographic structure. Specifically, our objectives were to: i) characterise the flower visitor guild of A. saxatilis; and ii) compare the visitation rate, pollination success, seed abortion rate and resulting population structure between the translocated and two natural populations.

\section{Material and methods}

\subsection{Study species}

Aeollanthus saxatilis is an herbaceous metallophyte that can reach a height of $25 \mathrm{~cm}$ (Malaisse et al., 2016). Individuals can produce several tubers, each is capable of producing one or several stems, depending on the plant's stage development (Fig. 1). For this study, we considered the ramet of $A$. saxatilis - one tuber and all the stems emerging from it. The flowering season extends from January to March. During this time, each reproductive stem produces one floral scape of around eight nodes. Both purple flowers of each node are receptive at the same time, as soon as the two flowers of the preceding node begin to fade. The corolla is violet and the tube is $5-10 \mathrm{~mm}$ long. The corolla closes during the night (LA, pers. obs., 2018). The fruit is schizocarpic, with four single-seeded mericarps (henceforth referred to as seeds) contained in a circumscissile fruiting calyx composed of four dark nutlets (Malaisse et al., 2016). The seeds are between $700 \mu \mathrm{m}$ and $1 \mathrm{~mm}$ in diameter. The weight of 1000 seeds is ca. $0.054 \mathrm{~g}$. A preliminary experiment of hand pollination, carried out under controlled conditions, indicated that the species is strictly allogamous (data not shown). The area of occupancy of $A$. saxatilis is estimated at $48 \mathrm{~km}^{2}$, with populations that never exceed $1 \mathrm{~km}^{2}$. Due to this restricted area of occupancy, A. saxatilis appears as 'Near Threatened' on the IUCN's Red List of endangered species (Meersseman et al., 2014). Among the 19 populations known in 2010 (Meersseman et al., 2014). All are located in mining areas and are threatened in the short or medium term. Only three remaining natural populations could be found between the cities of Tenke and Fungurume, two of which were available for sampling in this study.

\subsection{Study area and populations}

The study was carried out in the southeastern DRC, at three sites located in the region of Fungurume $\left(10.62^{\circ} \mathrm{S}, 26.32^{\circ} \mathrm{E}\right)$ (Boisson et al., 2016). The region has about $40 \mathrm{Cu}-\mathrm{Co}$ outcrops that form a complex

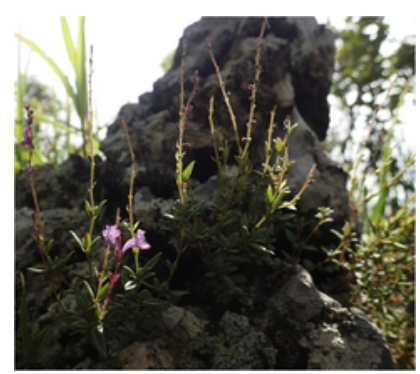

Fig. 1. Aeollanthus saxatilis growing on a cellular siliceous rock in a natural population near Fungurume, Democratic Republic of Congo. 
of hills, the altitudes of which range from $1200 \mathrm{~m}$ to $1400 \mathrm{~m}$ (François, 1988). This region experiences a warm, mild temperate climate, with a dry winter season, corresponding to the Cwa type in the Köppen-Geiger classification (Climate-data.org, 2018). The rainy season extends from November to March, and the dry season from May to September. The average annual temperature is $20.9^{\circ} \mathrm{C}$, and the average annual precipitations reach $1081 \mathrm{~mm}$ (Climate-data.org, 2018). Katangan ecosystems are intentionally burnt almost every year (Le Stradic et al., 2016).

The two remaining natural populations (NP1 and NP2) of $A$. saxatilis located in the region of Fungurume were selected to serve as reference sites for this assessment of restoration success. The region has been historically dominated by the naturally-open, dry forest called miombo. This forest is dominated by the Caesalpinioideae family, and the canopy height is less than $15 \mathrm{~m}$ (BM Campbell, 1996). The region of Fungurume is being urbanised, and the outcrops are operated by mining companies. Patches of natural metallophyte vegetation and miombo still exist, and are temporarily protected.

NP1 is located on the CSR located at the crest of a hill partly covered with miombo trees. The site is currently subject to artisanal mining, but the human pressure remains low. NP1 is spread over more than $1200 \mathrm{~m}^{2}$. NP2 is developed on the CSR located on top and on the upper western slope of a hill with an area of $900 \mathrm{~m}^{2}$. The pressure resulting from artisanal mining has been rising over recent years, and is now significant (BS, pers. comm., 2018). The hill is covered with miombo trees.

In this area, so-called 'reconstructed ecosystems', located $3 \mathrm{~km}$ north from NP1 and NP2, contain translocated populations of endemic species, and are expected to include all the three plant communities (i.e. steppe, steppic savanna, chasmophytic vegetation). The translocation of an A. saxatilis population to the receptor site occurred in 2014, four years prior to this study. The CSRs were mechanically translocated using machinery during the rainy season of 2014. The CSRs were spread over a targeted zone of the receptor site to simulate a density equivalent to that of the donor site. Those translocated CSRs originated from two $\mathrm{Cu}$-Co outcrops in the Fungurume region that are now operated by mining companies. This translocated population (referred as TP) covers an area of $3000 \mathrm{~m}^{2}$, reflecting its original size, and has not been exposed to further disturbances since the reconstructed ecosystem was completed in 2014. The site topography is negligible, and there are no trees on the site or in the surrounding area. Field data collection from the three populations took place at the end of the 2018 rainy season, from March 6-22.

\subsection{Ramet demographic structure and seed set}

Based on the area occupied by each population, we first validated the size of the population, and then randomly marked 10 CSRs hosting A. saxatilis to be representative of the occupied area at the site. On each marked CSR, we plotted one $50 \mathrm{~cm}$ x $50 \mathrm{~cm}$ quadrats, centred on an individual of $A$. saxatilis. The number of ramets and number of stems from each ramet in the quadrats were counted. All ramets with visible signs of flower production (floral buds, flowers, fruits or scars left by fallen fruits) were recorded as 'breeding ramets'.

Each quadrat was then subdivided into nine $(3 \times 3)$ equal subquadrats. On the ramet closest to the centre of each subquadrat (called 'focal ramets'), we collected and counted all the mature fruits during two collections performed between March 6 and 10, and 19 and 22. There were one to nine focal ramets per quadrat, depending on the ramet density and their distribution in the quadrat. Among the focal ramets, three breeding ramets per quadrat (when possible, otherwise one or two) were randomly selected to assess pollination success and abortion rate (totalling 23 in the TP, 20 in NP1 and 29 in NP2). For each of these, the number of fruiting calyces and the number of vi- able and aborted seeds contained in each fruiting calyx were counted under a binocular microscope (Euromex Nexius Zoom 1703-B). Vacant locules of the fruit, indicating that seeds had already been released from the fruiting calyx, were also counted as viable seeds. In the locules, mature (i.e. dark brown) or immature (i.e. light green) seeds with robust, rounded and smooth surfaces were considered viable. Seeds that did not meet these criteria (i.e. those having physical abnormalities or being flat) were considered as aborted. The pollination success was calculated for each breeding ramet, defined as the proportion of fruiting calyces containing at least one viable seed, considering that these resulted from successfully visited flowers. The abortion rate per breeding ramet was calculated as the proportion of aborted seeds in the fruiting calyces resulting from successfully visited flowers.

\subsection{Flower visitors}

From the 10 quadrats placed in each population, six were selected for recording flower visitors. For each of those 18 quadrats, three observation sessions of $20 \mathrm{~min}$ were carried out. To the extent possible, given the organisational constraints, these were distributed equally throughout the day, from 7.00 a.m. to 7.00 p.m., and were chosen to cover sunny and cloudy conditions at the same frequency for the three populations. Before each session, the number of floral units contained in the quadrat was determined. All insects visiting any flower in the quadrat during an observation session were recorded and captured with a net for accurate identification by specialists; a total of 12 insects were captured inside the quadrats. For a comprehensive documentation of the visitor guild, seven additional insects that visited the $A$. saxatilis flowers were captured outside of the quadrats. The Hymenoptera were identified by Alain Pauly and the Diptera by Kurt Jordaens on the basis of six to 10 pictures per specimen, taken with a Euromex Nexius Zoom 1703-B binocular microscope mounted with a camera.

The visitation rate was defined as the number of visits in a quadrat (all insect species together) per observation session.

\subsection{Data analysis}

We compared the ramet density (i.e. number of ramets per square metre) between the populations using a one-way analysis of variance (ANOVA), followed by Tukey HSD post-hoc tests. To compare the ramet demographic structures of the natural and translocated populations, the stem number (a proxy for ramet development stage) distributions of the three populations were compared using the Kolmogorov-Smirnov test. We also compared the proportion of breeding ramets (i.e. those having produced flowers during the 2018 flowering season) between the translocated and natural populations using a one-way ANOVA, with population being the fixed factor. Because of high heteroscedasticity, the proportion of one-stemmed ramets per quadrat (as a proxy for recruitment) was compared between the populations, using a non-parametric pairwise Wilcoxon test.

We compared pollination success and abortion rate between populations, using ANOVA with a mixed-effect model, followed by Tukey HSD post-hoc tests. Population was considered to be the fixed factor, and ramet was used as a grouping factor.

To compare visitation rates between the translocated and natural populations, we performed an analysis of covariance, with population as the fixed factor and the number of floral units as the covariate. The data were arcsine-transformed to improve the homoscedasticity. Except where otherwise stated, the assumptions of homoscedasticity and normality were verified prior to parametric testing. A significance threshold of 0.05 was adopted for all the statistical analyses. All analyses were performed using R version 3.3.2 (R Development Core Team, 2010). 


\section{Results}

\subsection{Ramet demographic structure and seed set}

The ramet density in the TP (mean \pm SE: $59.2 \pm 14.1$ ramets. $\mathrm{m}^{-2}$ ) was not significantly different from that of NP1 (100.8 \pm 15.1 ramets. $\mathrm{m}^{-2}$; Tukey test TP vs NP1 $p=0.244$ ), but was significantly lower than in NP2 (141.6 \pm 19.1 ramets. $\mathrm{m}^{-2}$; Tukey test TP vs NP2 $p=$ 0.004). Despite this, the ramet demographic structure of the TP did not significantly differ from those of NP1 (Kolmogorov-Smirnov test: $D=0.27 ; p=0.24$ ) or NP2 (Kolmogorov-Smirnov test: $D=0.30 ; p=$ 0.13 ) (Fig. 2). In the three populations, a similar decline in the number of ramets with number of stems was observed. Similarly, there was no significant difference in the proportion of breeding ramets between the TP (mean \pm SE: $56.41 \pm 8.55 \%$ ) and NP1 (51.16 $\pm 7.03 \%$ ), or between the TP and NP2 $(58.85 \pm 5.03 \%)\left(F_{2,27}=0.31, p=0.73\right)$. Recruitment was lower in the TP (mean \pm SE: $25.89 \pm 7.63 \%$ of single-stemmed ramets per quadrat) than in NP1 (47.09 $\pm 3.08 \%)$, but this difference was only marginally significant (Wilcoxon test: $p=$ 0.08 ). Recruitment in the TP did not significantly differ from that in NP2 $(26.61 \pm 3.10 \%)$ (Wilcoxon test: $p=0.76$ ).

Analysis revealed no significant difference in the pollination success between the TP and NP1 and NP1 $\left(F_{2,69}=0.84, p=0.44\right)$, being 77.33 $\pm 5.64 \%$ (mean $\pm \mathrm{SE}$ ), $84.52 \pm 4.59 \%$ and $68.34 \pm 6.55 \%$, respectively, for the TP, NP1 and NP2. Nor was the mean abortion rate per breeding ramet significantly different in the TP $(28.49 \pm 2.75 \%)$ from NP1 $(25.54 \pm 3.02 \%)$ or NP2 $(38.47 \pm 3.56 \%)\left(F_{2,65}=5.32, p=\right.$ 0.09).

\subsection{Flower visitors}

Aeollanthus saxatilis flowers were visited exclusively by Hymenoptera (68\% of observed visits) and Diptera (32\% of observed visits). Identification of the captured insects revealed seven genera of Hymenoptera, belonging to the families Apidae and Halictidae, and two genera of Diptera, both belonging to the family Syrphidae (Table 1). Among these captured specimens, only two Diptera could be identified to the species level - Ischiodon aegyptius Wiedmann, 1830 and Paragus borbonicus Macquart, 1842. The third identified Diptera taxon also belonged to the genus Paragus, but was part of the longiventris group, which contains an unknown number of sibling species. Flower visitors of the Apidae family belonged to four genera - Amegilla Friese, 1897, Braunsapis Michener, 1969, Ceratina Latreille, 1802 and Liotrigona Moure, 1961. Flower visitors of the Halictidae family belonged to three genera - Lasioglossum Curtis, 1833, Leuconomia Pauly, 1980 and Thrinchostoma de Saussure, 1891. Another Diptera specimen was captured, but could not be identified, and five Hymenoptera were observed, but could not be captured and thus were also not identified.

The mean visitation rate was lower in the TP (mean \pm SE: $0.17 \pm$ 0.09 visits per observation session of $20 \mathrm{~min})$ and NP1 (0.17 \pm 0.09$)$ than in NP2 $(0.56 \pm 0.15)$, but the difference was only marginally significant $\left(F_{2,49}=2.95, p=0.06\right)$. The effect of the number of floral units on the visitation rate was not significant $\left(F_{1,49}=1.44, p=0.24\right)$.

The most frequent visitors belonged to the genus Amegilla. All observed insects visited the interior of the flower, and several were seen visiting flowers of other species.

\section{Discussion}

Translocation methods have recently been highlighted as being promising for the long-term restoration of metallophyte communities experiencing rapid decline (Le Stradic et al., 2016). The successful re-establishment of plant assemblages following the translocation of topsoil (Cobbaert, Rochefort, \& Price, 2004; Jaunatre, Buisson, \& Dutoit, 2012) or vegetation mats (Le Stradic et al., 2016) has been demonstrated, but these methods are inadequate for chasmophytic plants, especially when they grow on large pieces of rock. In addition, if the establishment of plant species and vegetation development are necessary, translocation may not be sufficient to ensure the long-term persistence of populations, as plants interact with other organisms in many steps of their life-cycles.
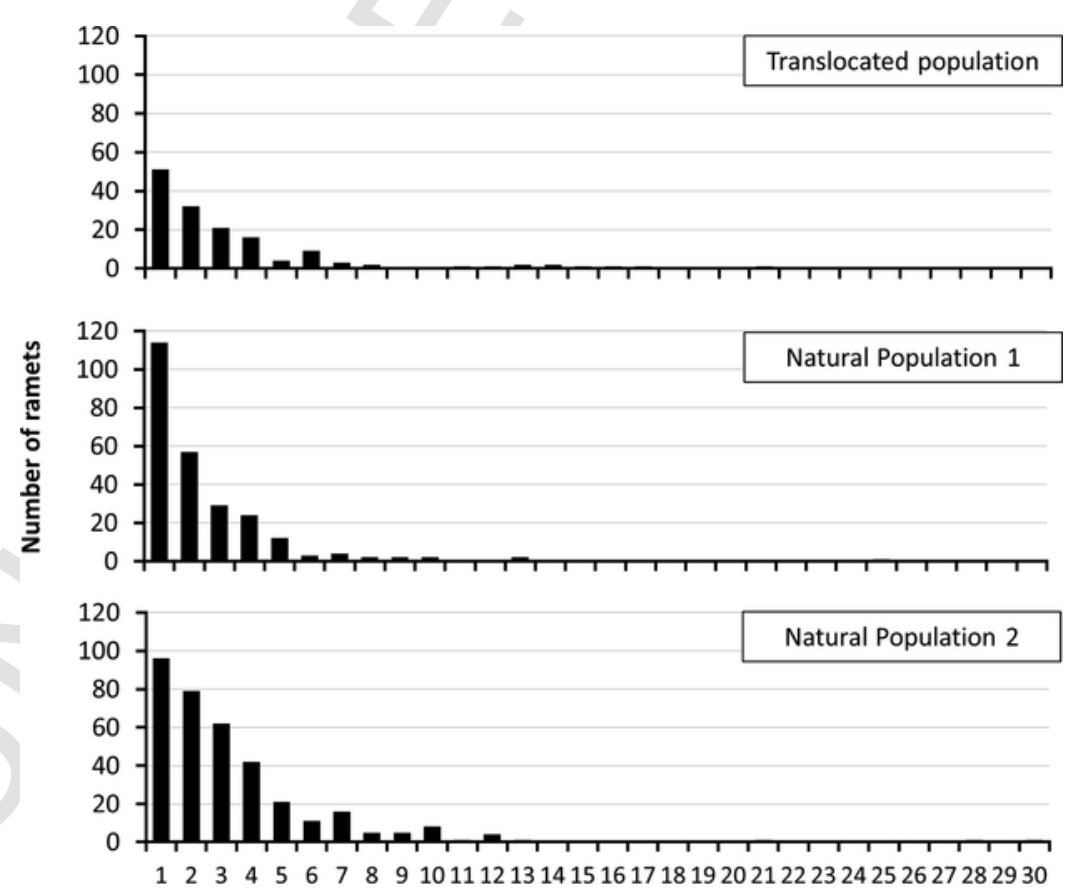

Number of stems per ramet

Fig. 2. Ramet demographic structure of the three populations of Aeollanthus saxatilis expressed as number of stems per number of ramets. 
Table 1

Details of insect flower-visitors of Aeollanthus saxatilis observed per 20-minute session. Observations were performed in March and April. $\mathrm{x}$ - specimen observed.

\begin{tabular}{|c|c|c|c|c|c|}
\hline \multirow[t]{2}{*}{ Taxon } & & \multirow[t]{2}{*}{$\begin{array}{l}\text { Number of } \\
\text { observed } \\
\text { individuals }\end{array}$} & \multicolumn{3}{|c|}{ Presence } \\
\hline & & & $\mathrm{TP}$ & NP1 & NP2 \\
\hline \multicolumn{6}{|l|}{ DIPTERA } \\
\hline \multicolumn{6}{|l|}{ Syrphidae } \\
\hline $\begin{array}{l}\text { Ischiodon Sack, } \\
1913\end{array}$ & $\begin{array}{l}\text { I. aegyptius } \\
\text { (Wiedemann, } \\
1830 \text { ) }\end{array}$ & 3 & $\mathrm{x}$ & & $\mathrm{x}$ \\
\hline Paragus & P. borbonicus & 4 & $\mathrm{x}$ & & $\mathrm{x}$ \\
\hline \multirow{2}{*}{ Latreille, 1804} & Macquart, 1842 & & & & \\
\hline & $\begin{array}{l}\text { Paragus sp. } \\
\text { (longiventris } \\
\text { group) }\end{array}$ & 1 & $\mathrm{x}$ & & $\mathrm{x}$ \\
\hline $\begin{array}{l}\text { Unidentified } \\
\text { specimen } 1\end{array}$ & & 1 & & & $\mathrm{x}$ \\
\hline \multicolumn{6}{|l|}{ HYMENOPTERA } \\
\hline \multicolumn{6}{|l|}{ Apidae } \\
\hline $\begin{array}{l}\text { Amegilla Friese, } \\
1897\end{array}$ & Amegilla sp. & 7 & $\mathrm{x}$ & $\mathrm{x}$ & $\mathrm{x}$ \\
\hline \multicolumn{6}{|l|}{ Michener, 1969} \\
\hline $\begin{array}{c}\text { Ceratina } \\
\text { Latreille, } 1802\end{array}$ & Ceratina sp. & 1 & & & $\mathrm{x}$ \\
\hline \multicolumn{6}{|l|}{ Moure, 1961} \\
\hline \multicolumn{6}{|l|}{ Halictidae } \\
\hline \multicolumn{6}{|l|}{ Curtis, 1833} \\
\hline Leuconomia & Leuconomia sp. & 1 & $\mathrm{x}$ & & \\
\hline \multicolumn{6}{|l|}{ Pauly, 1980} \\
\hline $\begin{array}{c}\text { Thrinchostoma } \\
\text { de Saussure, } 1891\end{array}$ & $\begin{array}{l}\text { Thrinchostoma } \\
\text { sp. }\end{array}$ & 1 & & & $\mathrm{x}$ \\
\hline $\begin{array}{l}\text { Unidentified } \\
\text { specimen } 2\end{array}$ & & 1 & & $\mathrm{x}$ & \\
\hline $\begin{array}{l}\text { Unidentified } \\
\text { specimen } 3\end{array}$ & & 1 & & $\mathrm{x}$ & \\
\hline $\begin{array}{l}\text { Unidentified } \\
\text { specimen } 4\end{array}$ & & 1 & & $\mathrm{x}$ & \\
\hline $\begin{array}{l}\text { Unidentified } \\
\text { specimen } 5\end{array}$ & & 1 & & & $\mathrm{x}$ \\
\hline $\begin{array}{l}\text { Unidentified } \\
\text { specimen } 6\end{array}$ & & 1 & & & $\mathrm{x}$ \\
\hline Total & & 28 & & & \\
\hline
\end{tabular}

The present study is the first to examine the success of whole-rock translocation, and to investigate the mutualistic interactions of a metallophyte plant with insects. Slight differences were observed in visitor guild and ramet density between translocated and natural populations of $A$. saxatilis, but no difference in reproductive performance or ramet demographic structure was found in the populations. Rock translocation therefore appears to be a successful approach for this species.

The presence of a diverse guild of floral visitors affects the ability of translocated ecosystems to support reproductive populations. Not all potential pollinators contribute equally to the reproductive success of a plant species because this depends on their visiting frequency and their effectiveness in transferring pollen (Lemaitre, Pinto, \& Niemeyer, 2014; Monty et al., 2006).

The pollinator guild of the chasmophytic plants of Katanga is largely unknown. Our observations allowed a first list of the flower visitors of $A$. saxatilis to be compiled, among which several (if not most) are very likely to play a role in pollination, as all of them entered the flowers. In this study, the species richness of the flower-visiting insects in the translocated population (five species) was the same as in one of the natural populations, but the other natural population showed a higher species richness (11 species). Nevertheless, no deficiency was observed in the translocated population in terms of reproductive performance in comparison with the natural populations.
The majority of the identified taxa are known to be generalist pollinators, being relatively widespread in the Afrotropical region (Eardley, Kuhlmann, \& Pauly, 2010; Friedrich, 2018; Michener, 2000; Peter, Dold, Barker, \& Ripley, 2004), which probably helped in the recovery of a functional visitor guild at the receptor site. Considering all the flower visitors, the flower visitation rate observed in the translocated population was equivalent to that observed in the natural populations.

Unlike in several Labiata species (Akter, Biella, \& Klecka, 2017; Aluri, Vergara-Santana, \& Juarez, 1997), the number of floral units of A. saxatilis per quadrat did not significantly influence the frequency of visits. While relatively low, the observed mean visitation rate of 0.17 visits per $20 \mathrm{~min}$ and per quadrat in the translocated population seems sufficient to ensure seed production, allowing the development of seeds from $77 \%$ of the flowers per breeding ramet, on average - a percentage comparable to that of the natural populations. If flowers are receptive for eight consecutive days (LA, pers. obs., 2018) - that is, for $96 \mathrm{~h}$, assuming the flowers are only receptive during the $12 \mathrm{~h}$ of the day as these flower corollas close at night - each flower would be visited, on average, 2.7 times based on our observed visitation rate $\left(0.5\right.$ visits.quadrat $\left.{ }^{-1} . \mathrm{h}^{-1}\right)$ and the average number of floral units (17.6 flowers.quadrat $^{-1}$ ) in the translocated area.

However, even when the flowers were pollinated, $28 \%$ of the seeds did not develop. This could be linked to several post-pollination mechanisms, such as accidental auto-pollination resulting from flower visitation (Abrol, 2012; Collevatti, Estolano, Garcia, \& Hay, 2009) or maternal regulation of offspring quality, leading to the selective abortion of seeds with lower potential fitness (Collevatti et al., 2009). Alternatively, the flower visitors may have carried pollen from other species and saturated the pistils of $A$. saxatilis (Abrol, 2012). This latter hypothesis is more likely, given that almost all the floral visitors observed in this study were generalist species.

The overall reproductive performance observed in the translocated population did not significantly differ from those of the natural populations, as confirmed by the ramet demographic structure, which was also comparable between the translocated and natural populations. The shapes of the three distribution curves indicate a continuous regeneration, although the share of sexual reproduction cannot be distinguished from that of vegetative reproduction through tubers.

Our results suggest that there was no significant lack of mutualistic interaction in the translocated population compared to that in the reference natural populations, likely due to the generalist behaviour of the floral visitors. Four years after translocation, the receptor site seems to satisfy the required conditions for the maintenance of a reproductive and viable population of $A$. saxatilis. However, our assessment of the success of this rock translocation is based on direct comparison with two relict populations that were selected as references. It is thus assumed that these two populations are representative of the natural dynamics of $A$. saxatilis. Relict populations are subject to anthropogenic perturbations, however, notably through artisanal mining, and it cannot be excluded that ancient natural populations used to host higher species richnesses or pollinator abundances, and that the proportion of successfully pollinated flowers and recruitment may have been higher in those populations in the past. In addition, our sampling was relatively limited, and only covered up to the end of the flowering season, due to the restricted access to the mining sites for administrative and safety reasons.

The explanation associated with the IUCNs status of' Near Threatened' assigned to the species mentions an unknown population trend and a continuous decline in mature individuals (Meersseman et al., 2014). Despite that the decline is ongoing because of direct habitat destruction, this study brings encouraging data on the current demographic structure of the last natural populations in the Fungurume region, and demonstrates that satisfactory population dynamics can be expected in $A$. saxatilis populations following rock translocation. 
The other plant species constituting the chasmophytic plant community are expected to experience similar restoration success. CSR translocation is thus encouraging for the medium term for conserving populations of threatened chasmophytic species, and further studies should also confirm its success in the long term (e.g. by identifying the potential for new individuals to become established).

\section{Funding}

No funding was received for this work

\section{Declaration of Competing Interest}

No conflict of interest exists.

\section{Acknowledgements}

This study was made possible thanks to the financial intervention of the Fonds de Mobilite ULiège, Belgium and the Fondation pour Favoriser la recherche sur la Biodiversité en Afrique of Belgium. The authors also thank Tenke Fungurume Mining sarl (TFM, CMOC International) for their logistical support, and especially H. Kabulo, C. Kabey, L. Banza and G. Handjila for the data collection. We also thank Maxime Séleck for his expertise about the species. Sincere considerations go to A. Pauly (Belgium), M. Aubert (Belgium), K. Jordaens (Belgium) and M. De Meyer (Belgium) for their help with the Hymenoptera and Diptera identifications.

\section{References}

Abrol, D.P., 2012. Pollination biology. Springer Netherlands, Dordrecht, https://doi.org/ 10.1007/978-94-007-1942-2

Akter, A., Biella, P., Klecka, J., 2017. Effects of small-scale clustering of flowers on pollinator foraging behaviour and flower visitation rate. PloS One 12 (11), e0187976https: //doi.org/10.1371/journal.pone.0187976.

Aluri, J.S.R., Vergara-Santana, M.I., Juarez, S.L., 1997. Floral ecology, carinal-lobe release, pollination and reproductive success in the wild and domesticated forms of Hyptis suaveolens (L.) poit. (Lamiaceae) in Mexico. Plant Species Biology 12 (2-3), 61-68. https://doi.org/10.1111/j.1442-1984.1997.tb00158.x.

Baker, A.J.M., Ernst, W.H.O., Van der Ent, A., Malaisse, F., Ginocchio, R., 2010. Metallophytes: The unique biological resource, its ecology and conservational status in Europe, central Africa and Latin America. In: Batty, L., Hallberg, K. (Eds.), Ecology of industrial pollution. Cambridge University Press, Cambridge (UK), pp. 7-40.

Boisson, S, Lebrun, J., Séleck, M., Mahy, G., 2012. Copperflora website. Retrieved May 20, 2013, from http://www.copperflora.org.

Boisson, S., Faucon, M.-P., Le Stradic, S., Lange, B., Verbruggen, N., Garin, O., ... Mahy, G., 2017. Specialized edaphic niches of threatened copper endemic plant species in the D.R. Congo: Implications for ex situ conservation. Plant and Soil 413 (1-2), 261-273. https://doi.org/10.1007/s11104-016-3095-7.

Boisson, S., Monty, A., Lebrun, J., Séleck, M., Mahy, G., 2016. Edaphic niches of metallophytes from southeastern Democratic Republic of Congo: Implications for post-mining restoration. Journal for Nature Conservation 33, 18-24. https://doi.org/10.1016/ j.jnc.2016.06.002

Boisson, S., Monty, A., Séleck, M., Ngoy, M., Faucon, M., Mahy, G., 2020. Ecological niche distribution along soil toxicity gradients: Bridging theoretical expectations and metallophyte conservation. Ecological Modelling 415 (October), 108861https://doi.org/10. 1016/j.ecolmodel.2019.108861

Brooks, R.R., Baker, A.J.M., Malaisse, F., 1992. Copper flowers. Research and Exploration 8 (3), 338-351, Retrieved from http://kbd.kew.org/kbd/detailedresult. do?id $=292680$

Bullock, J.M., 1998. Community translocation in Britain: Setting objectives and measuring consequences. Biological Conservation 84 (3), 199-214, article.

Byers, D.L., Chang, S.-M., 2017. Studying plant-pollinator interactions facing climate change and changing environments. Applications in Plant Sciences 5 (6)https://doi. org/10.3732/apps.1700052.

Cailteux, J.L.H., Kampunzu, A.B., Lerouge, C., Kaputo, A.K., Milesi, J.P., 2005. Genesis of sediment-hosted stratiform copper-cobalt deposits, central African Copperbelt. Journal of African Earth Sciences 42 (1-5), 134-158. https://doi.org/10.1016/j.jafrearsci. 2005.08.001.

Campbell, BM, 1996. In: Campbell, B. (Ed.), The miombo in transition: Woodlands and welfare in Africa. Center for International Forestry Research (CIFOR), Bogor, Indonesia.

Climate-data.org, 2018. Climate of fungurume (DRC). Retrieved September 28, 2018, from https://fr.climate-data.org/location/765254/.

Cobbaert, D., Rochefort, L., Price, J.S., 2004. Experimental restoration of a fen plant community after peat mining. Applied Vegetation Science 7 (2), 209-220. https://doi.org/ 10.1111/j.1654-109X.2004.tb00612.x.
Collevatti, R.G., Estolano, R., Garcia, S.F., Hay, J.D., 2009. Seed abortion in the bat pollinated Neotropical tree species, Caryocar brasiliense (Caryocaraceae). Botany 87 (11), 1110-1115. https://doi.org/10.1139/B09-054.

Cropper, S.C., Calder, D.M., 1990. Systematics and evolution the floral biology of thelymitra epipactoides (orchidaceae), and the implications of pollination by deceit on the survival of this rare orchid. Plant systematics and evolution Vol. 170, Retrieved from https://link.springer.com/content/pdf/10.1007/BF00937846.pdf.

Delhaye, G., Violle, C., Séleck, M., Ilunga wa Ilunga, E., Daubie, I., Mahy, G., ... Meerts, P., 2016. Plant traits variation along a copper-cobalt contamination gradient: A community-level perspective exploring the relative importance of species turnover and within species variation. Journal of Vegetation Science

Duvigneaud, P., Denaeyer-De Smet, S., 1963. Cuivre et végétation au Katanga [Copper and vegetation in Katanga]. Bulletin de La Société Royale de Botanique de Belgique 96, 93-224.

Eardley, C., Kuhlmann, M., Pauly, A., 2010. Les genres et sous-genres d'abeilles de I'Afrique subsaharienne. Retrieved from https://scholar.google.be/scholar?hl=fr\&as $\mathrm{sdt}=0 \% 2 \mathrm{C} 5 \& \mathrm{q}=$ Eardley $+\mathrm{C} . \% 2 \mathrm{C}+$ Kuhlmann + M. $+\% 26+$ Pauly + A. $\% 2 \mathrm{C}+2010$. + Les + genres + et + sous-

genres $+\mathrm{d} \% \mathrm{E} 2 \% 80 \% 99$ abeilles $+\mathrm{de}+1 \% \mathrm{E} 2 \% 80 \% 99 \mathrm{Afrique}+$ subsaharienne $\% 2 \mathrm{C}+$ trad . + A. + Pauly. + 2e +\%C3\%A9d. + Belgium +\%3A + ABC + TAXA. + \&btnG $=$.

Faucon, M.-P., Meersseman, A., Shutcha, M.N., Mahy, G., Luhembwe, M.N., Malaisse, F., .. Meerts, P., 2010. Copper endemism in the Congolese flora: A database of copper affinity and conservational value of cuprophytes. Plant Ecology and Evolution 143 (1), 5-18. https://doi.org/10.5091/plecevo.2010.411.

Faucon, M.P., Le Stradic, S., Boisson, S., wa Ilunga, E.I.E.I., Séleck, M., Lange, B., .. Mahy, G., 2016. Implication of plant-soil relationships for conservation and restoration of copper-cobalt ecosystems. Plant and Soil 403 (1-2), 153-165. https://doi.org/ 10.1007/s11104-015-2745-5.

Fay, I., Barton, M.D., 2012. Alteration and ore distribution in the proterozoic mines series, tenke-fungurume Cu-Co district, Democratic Republic of Congo. Mineralium Deposita 47 (5), 501-519.

Forup, M.L., Henson, K.S.E., Craze, P.G., Memmott, J., 2007. The restoration of ecological interactions: Plant-pollinator networks on ancient and restored heathlands. Journal of Applied Ecology 45 (3), 742-752. https://doi.org/10.1111/j.1365-2664.2007.01390. $\mathrm{x}$.

François, A., 1988. Synthèse géologique sur l'Arc cuprifère du Shaba (Rép.du Zaïre). Société Belge de Géologie, Centenaire (1987), 15-65.

Friedrich, M., 2018. Ischiodon aegyptius (Wiedmann, 1830). Retrieved July 23, 2018, from https://arthropodafotos.de/dbsp.php?lang = eng\&sc $=1 \&$ ta $=$ t_38_dipt_bra_syr\& sci $=$ Ischiodon $\&$ scisp $=$ aegyptius .

Giovanetti, M., Cervera, J.C., Andrade, J.L., 2007. Pollinators of an endemic and endangered species, Mammillaria gaumeri (Cactaceae), in its natural habitat (Coastal dune) and in a botanical garden. Madrono 54 (4), 286-292. https://doi.org/10.3120/00249637(2007)54

Harzé, M., Monty, A., Boisson, S., Pitz, C., Hermann, J.-M., Kollmann, J., .. Mahy, G., 2018. Towards a population approach for evaluating grassland restoration-a systematic review. Restoration Ecology https://doi.org/10.1111/rec.12663.

Ilunga wa Ilunga, E., Séleck, M., Colinet, G., Meerts, P., Mahy, G., 2013. Small-scale diversity of plant communities and distribution of species niches on a copper rock outcrop in Upper Katanga, DR Congo. Plant Ecology and Evolution 146 (2), 173-182. https:// doi.org/10.5091/plecevo.2013.816.

International Council on Mining and Minerals (ICMM), 2006. Good practice guidance for mining and biodiversity. ICMM., London.

Jaunatre, R., Buisson, E., Dutoit, T., 2012. First-year results of a multi-treatment steppe restoration experiment in La Crau (Provence, France). Plant Ecology and Evolution 145 (1), 13-23.

Kaiser-Bunbury, C.N., Mougal, J., Whittington, A.E., Valentin, T., Gabriel, R., Olesen, J.M., ... Blüthgen, N., 2017. Ecosystem restoration strengthens pollination network resilience and function. Nature 542 (7640), 223-227. https://doi.org/10.1038/ nature21071.

Kato, M, Kawakita, A (Eds.), 2017. Obligate pollination mutualism. Springer Japan, Tokyo, https://doi.org/10.1007/978-4-431-56532-1.

Kearns, C.A., Inouye, D.W., Waser, N.M., 1998. ENDANGERED MUTUALISMS: The conservation of plant-pollinator interactions. Annual Review of Ecology and Systematics 29 (1), 83-112. https://doi.org/10.1146/annurev.ecolsys.29.1.83.

Kirchner, F., Luijten, S.H., Imbert, E., Riba, M., Mayol, M., González-Martínez, S.C., .. Mayol, M., 2005. Effects of local density on insect visitation and fertilization success in the narrow-endemic Centaurea corymbosa (Asteraceae). OIKOS 111, 130-142. https: //doi.org/10.1111/j.0030-1299.2005.14022.x, Retrieved from.

Lange, B., Faucon, M.-P., Meerts, P., Shutcha, M., Mahy, G., Pourret, O., 2014. Prediction of the edaphic factors influence upon the copper and cobalt accumulation in two metallophytes using copper and cobalt speciation in soils. Plant and Soil 379 (1-2), 275-287. https://doi.org/10.1007/s11104-014-2068-y.

Le Stradic, S., Séleck, M., Lebrun, J., Boisson, S., Handjila, G., Faucon, M.P., ... Mahy, G., 2016. Comparison of translocation methods to conserve metallophyte communities in the Southeastern D.R. Congo. Environmental Science and Pollution Research 23 (14), 13681-13692. https://doi.org/10.1007/s11356-015-5548-6.

Lemaitre, A.B., Pinto, C.F., Niemeyer, H.M., 2014. Generalized pollination system: Are floral traits adapted to different pollinators?. Arthropod-Plant Interactions 8 (4), 261-272. https://doi.org/10.1007/s11829-014-9308-1.

Malaisse, F., Brooks, R.R., Baker, A.J.M., 1994. Diversity of vegetation communities in relation to soil heavy metal content at the Shinkolobwe copper/cobalt/uranium mineralization, upper Shaba, Zaire. Belgian Journal of Botany 127 (1), 3-16.

Malaisse, F., Schaijes, M., D’Outreligne, C., 2016. Copper-cobalt Flora of Upper Katanga and Copperbelt: Field guide. Les Presses agronomiques de Gembloux.

Meersseman, A., Faucon, M.-P., Meerts, P., Mahy, G., Malaisse, F., Ngongo Luhembwe, M., 2014. Aeollanthus saxatilis.

Michener, C.D., 2000. The bees of the world. Retrieved from Johns Hopkins University Presshttps://books.google.be/books?id = bu_1gmY13FIC. 
Montalvo, A.M., Williams, S.L., Rice, K.J., Buchmann, S.L., Cory, C., Handel, S.N., ... Robichaux, R., 1997. Restoration biology : A population biology perspective. Restoration Ecology 5 (4), 277-290.

Monty, A., Saad, L., Mahy, G., 2006. Bimodal pollination system in rare endemic Oncocyclus irises (Iridaceae) of Lebanon. Canadian Journal of Botany 84 (8), 1327-1338. https://doi.org/10.1139/b06-081.

Mudd, G.M., Jowitt, S.M., 2018. Growing global copper resources, reserves and production: Discovery is not the only control on supply. Economic Geology 113 (6), 1235-1267. https://doi.org/10.5382/econgeo.2018.4590.

Muyumba, D.K., Liénard, A., Mahy, G., Ngongo, M., 2015. Caractérisation des systèmes sols-plantes dans les collines de l' arc cuprifère du Katanga (synthèse bibliographique). Biotechnologie, Agronomie, Société et Environnement 19 (2), 197-207.

Peter, C.I., Dold, A.P., Barker, N.P., Ripley, B.S., 2004. Pollination biology of Bergeranthus multiceps (Aizoaceae) with preliminary observations of repeated flower opening and closure. South African Journal of Science 100 (11-12), 624-629, Retrieved from https://journals.co.za/content/sajsci/100/11-12/EJC96175.

$\mathrm{R}$ Development Core Team, 2010. A language and environment for statistical computing. R Foundation for Statistical Computing, Vienna (Austria).

Saad, L., Parmentier, I., Colinet, G., Malaisse, F., Faucon, M.-P., Meerts, P., ... Mahy, G., 2012. Investigating the vegetation-soil relationships on the copper-cobalt rock outcrops of Katanga (D. R. Congo), an essential step in a biodiversity conservation plan.
Restoration Ecology 20 (3), 405-415. https://doi.org/10.1111/j.1526-100X.2011.00786.

Séleck, M., Bizoux, J.-P., Colinet, G., Faucon, M.-P., Guillaume, A., Meerts, P., ... Mahy, G., 2013. Chemical soil factors influencing plant assemblages along copper-cobalt gradients: Implications for conservation and restoration. Plant \& Soil 373 (1/2), 455-469. https://doi.org/10.1007/s11104-013-1819-5.

Society for Ecological Restoration, 2004. The SER International primer on ecological restoration. 2. https://doi.org/S34.

Stpiczyńska, M., Zych, M., 2017. Plant-animal interactions are a key to understand biodiversity. Acta Agrobotanica 70 (1)https://doi.org/10.5586/aa.1711.

Tarasjev, A., 2005. Impact of genet size and flowering stage on fruit set in Iris pumila L. clones in wild. Acta Oecologica 27 (2), 93-98. https://doi.org/10.1016/J.ACTAO. 2004.09.007.

Tepedino, V.J., Sipes, S.D., Griswold, T.L., 1999. The reproductive biology and effective pollinators of the endangered beardtongue Penstemon penlandii (Scrophulariaceae). Plant Systematics and Evolution 219 (1-2), 39-54. https://doi.org/10.1007/ BF01090298.

United Nations, 1992. Convention on biological diversity, 30. Retrieved from http://www. cbd.int/doc/legal/cbd-en.pdf.

Vanbergen, A.J., Baude, M., Biesmeijer, J.C., Britton, N.F., Brown, M.J.F., Brown, M., .. Wright, G.A., 2013. Threats to an ecosystem service: Pressures on pollinators. Frontiers in Ecology and the Environment https://doi.org/10.1890/120126. 